Красинский Владислав Вячеславович, кандидат юридических наук

Источник опубликования: Красинский B.B. О правовом статусе неграждан // Военноюридический журнал. М.: ИГ Юрист, 2007. № 4. С. 2-7; www.krasinskiy.ru

\title{
О ПРАВОВОМ СТАТУСЕ НЕГРАЖДАН
}

После распада СССР к власти в странах Балтии пришли представители националистических сил. Их главной задачей в тот период времени стало формирование социально-экономической структуры и идеологии нового постсоветского общества, в рамках которого не предусматривалось место для русскоязычного населения. Результатом выражения такой политики стало появление блока законов и подзаконных актов, закрепляющих политические, экономические и социальные привилегии «коренного» населения за счет ущемления прав русских.

Одним из «правовых» феноменов национально-государственного строительства и законодательной практики стран Балтии стало возникновение юридической и социальной категории «неграждане», не имеющей аналогов в современном цивилизованном мире ${ }^{1}$.

Вместе с тем история свидетельствует, что новое - это хорошо забытое старое. Человечество уже сталкивалось с похожими социально-политическими явлениями.

В 1933 г. после прихода к власти Гитлера в Германии была установлена национал-социалистическая диктатура. Главным врагом Третьего Рейха были объявлены евреи, обвиненные во всех бедах великой Германии. Для защиты от «недочеловеков» появились дискриминирующие права евреев Нюрнбергские законы о гражданстве и расе, удивительным образом напоминающие современные прибалтийские законы о негражданах ${ }^{2}$.

Необходимо отметить, что упоминаемые законодательные акты использовались (продолжают использоваться) правящими кругами прежде всего как средство принудительной национальной ассимиляции и борьбы с расово чуждыми народами. Поэтому расовые законы нацистской Германии и прибалтийские законы о негражданах имеют очевидные сходства: 
- Во-первых, они основаны на презумпции существования в государстве определенной социальной общности (евреи - в нацистских законах, неграждане (русские) - в прибалтийских законах о негражданах), подозреваемой в нелояльности к существующему государственно-политическому режиму ${ }^{3}$. В подтверждение истинности этого кощунственного тезиса можно привести фрагмент официального интервью действующего президента Латвии Вайры Вике-Фрейберги печатному изданию «Аргументы и факты», в котором она заявила: «В Латвии у нас имеется проблема наплыва русскоязычного населения и его недостаточной лояльности строю» ${ }^{4}$.

- Во-вторых, эти законы вводят значительное ограничение объема правосубъектности «расово-неполноценных элементов». Нацистские расовые законы и ведомственные инструкции министерств внутренних дел, юстиции, труда и экономики германского Рейха (от 11 апреля 1933 г., от 23 июля 1938 г., от 17 августа 1938 г., от 12 ноября 1938 г. и др.) лишали евреев политических, социальных, культурных и религиозных прав, устанавливали запреты на профессии. Существующие сегодня в латвийских законах ограничения неграждан в политических, социальных, экономических правах прямо приравнивают их к лицам с ограниченной дееспособностью (таким как наркоманы, алкоголики, лица, осужденные за преступления, члены запрещенных и террористических организаций). В латвийских и эстонских законах упоминается несколько десятков профессий, которые не могут получить неграждане (судьи, прокуроры, дипломаты, полицейские, работники органов безопасности, пограничники, землемеры, адвокаты, нотариусы, судебные исполнители и др. $)^{5}$. Неграждане не могут занимать определенные государственные и общественные должности (должности в воинских частях, должности государственной службы, должности судебных заседателей, должности в комиссиях и рабочих группах самоуправлений). Наиболее болезненным для неграждан является ущемление их социально-экономических прав (требование разрешения на работу, неравный учет трудового стажа, ограничения при проведении приватизации, покупке собственности в рассрочку, ущемление права на труд, на жилище и т.д. $)^{6}$. 
Кажущиеся на первый взгляд менее значимыми ограничения прав неграждан в сфере образования, науки и культуры на самом деле затрагивают коренные основы существования и самосознания народа. Принудительная национальная ассимиляция начинается именно с запрета на пользование родным языком, на свободный выбор языка общения, воспитания, обучения и творчества. Не случайно руководство нацистской Германии принципиальным вопросом считало вопрос о системе образования. Как отмечал Гиммлер в Записке об обращении с местным населением восточных областей, «для ненемецкого населения восточных областей не должно быть высших школ. Для него достаточно наличия четырехклассной народной школы. Целью обучения должно быть только: простой счет, самое большее до 500, умение расписаться... Умение читать не обязательно» ${ }^{7}$. Гитлер уточнял, что «для успеха нашего управления необходимы известные языковые предпосылки. А то ведь каждый житель будет уклоняться от выполнения немецких распоряжений под тем предлогом, что «не понял» их. По этой же причине необходимо обучать в школе не тому алфавиту, которым пользовались до сих пор» ${ }^{8}$.

Обвинительно-дискриминационный характер прибалтийских законов о негражданах нарушает фундаментальный принцип современного уголовного и административного права цивилизованных стран, - принцип субъективного вменения, в соответствии с которым запрещена ответственность без вины. Почему за действия советских карательных органов в 40-50 гг. XX века должны нести ответственность сотни тысяч невиновных людей, принадлежащих к русскоязычному населению стран Балтии в XXI веке 9 . Сторонники дискриминации неграждан оправдывают подобный подход восстановлением исторической справедливости и необходимостью искоренения наследия советского прошлого. Но если следовать такой логике, то потомки сегодняшних неграждан-изгоев получают полное право осуществить свое возмездие в будущем. Необходимо разорвать этот порочный круг и осознать, что существующие в странах Балтии дискриминационные ограничения прав неграждан влекут за собой их отстранение от участия в управлении делами общества и государства, ущемление возможности свободно осуществлять законную экономическую деятельность, свободно мыслить и выражать свое 
мнение, участвовать в культурной жизни и проживать в условиях, обеспечивающих достойное существование в государстве пребывания;

- В-третьих, упоминаемые законы роднит ультраправый националистический «дух» (так, на бывших солдат 15-й и 19-й латышских дивизий Waffen SS распространяется действие Закона Латвийской Республики 1995 г. «Об определении статуса политически репрессированного лица для пострадавших от коммунистического и нацистского режимов», им гарантируются льготные пенсии, бесплатное медицинское обслуживание, льготы при пользовании общественным транспортом и услугами по оплате налогов; в 1998 г. Сеймом Латвии были приняты поправки к Закону Латвийской Республики «О праздничных и памятных днях» об установлении 16 марта Днем латышского легиона СС) $)^{10}$.

Среди ученых-юристов распространено мнение, что право нацистской Германии не является правом в подлинном смысле этого слова, поскольку законы Третьего Рейха были недемократичными и несправедливыми. Возникает обоснованный вопрос: почему аналогичные нацистским недемократичные и несправедливые законы Эстонии и Латвии должны признаваться правом Евросоюза?

Средневековые особенности действующих в отношении неграждан законов (социальное неравенство, несоответствие объема прав неграждан объему их обязанностей, дискриминация) противоречат общеевропейским стандартам в гуманитарной сфере, общепризнанным принципам и нормам международного права ${ }^{11}$.

История знает примеры подобного отношения к людям (решение «еврейского вопроса» в нацистской Германии, расовая сегрегация в США, режим апартеида в ЮАР). Известно, что политические режимы, которые проводили такую политику, либо потерпели крушение, либо эволюционировали в формы государства с демократическим содержанием.

Необходимо подчеркнуть, что дискриминация т.н. неграждан в правах прямо противоречит нормам международных актов ООН, документов Совета Европы и стандартам ОБСЕ. 
Ни в одном из документов ООН (Всеобщая декларация прав человека от 10.12.1948 г., Конвенция по борьбе с дискриминацией в области образования от 15.12.1960 г., Конвенция МОТ о равноправии (в области социального обеспечения) 1962 г., Международная конвенция о ликвидации всех форм расовой дискриминации от 21.12.1965 г., Международный пакт о гражданских и политических правах от 16.12. 1966 г., Международный пакт об экономических, социальных и культурных правах от 16.12.1966 г., Декларация о правах лиц, принадлежащих к национальным или этническим, религиозным и языковым меньшинствам от 18.12 .1992 г. и др.) нет положений о возможности дискриминации и ущемлении прав человека по какому-либо признаку. Напротив, правовые акты ООН основаны на совершенно иных принципах и закрепляют другие нормативные положения.

Так, в соответствии со ст. 7 Всеобщей декларации прав человека «все люди имеют право на равную защиту от какой бы то ни было дискриминации...и от какого бы то ни было подстрекательства к такой дискриминации» ${ }^{12}$.

Международный пакт об экономических, социальных и культурных правах предусматривает, что правительства должны принимать в пределах имеющихся ресурсов поэтапные меры по защите прав каждого человека независимо от его гражданства на: труд (ст. 6); справедливые и благоприятные условия труда (ст. 7); создание профессиональных союзов (ст. 8); социальное обеспечение для каждого человека (ст. 9); достаточный жизненный уровень, включающий достаточное питание, одежду и жилище и непрерывное улучшение условий жизни (ст. 11); наивысший достижимый уровень физического и психического здоровья (ст. 12); образование (ст. 13); и участие в культурной жизни (ст. 15) ${ }^{13}$.

Статья 27 Международного пакта о гражданских и политических правах устанавливает: «В тех странах, где существуют этнические, религиозные и языковые меньшинства, лицам, принадлежащим к таким меньшинствам, не может быть отказано в праве совместно с другими членами той же группы пользоваться своей культурой, исповедовать свою религию и исполнять ее обряды, а также пользоваться родным языком» ${ }^{14}$.

Статья 2 Декларации о правах лиц, принадлежащих к национальным или этническим, религиозным и языковым меньшинствам, содержит аналогичные 
положения: «Лица, принадлежащие к национальным или этническим, религиозным и языковым меньшинствам (в дальнейшем именуемые лицами, принадлежащими к меньшинствам), имеют право пользоваться достоянием своей культуры, исповедовать свою религию и отправлять религиозные обряды, а также использовать свой язык в частной жизни и публично, свободно и без вмешательства или дискриминации в какой бы то ни было форме» ${ }^{15}$.

Против сегрегации и ущемления прав человека направлены многочисленные документы Совета Европы ${ }^{16}$. В частности, статья 14 Конвенции о защите прав человека и основных свобод от 04.11.1950 г. закрепляет, что «Пользование правами и свободами... гарантируется без дискриминации по какому - бы то ни было признаку: как-то... принадлежности к национальному меньшинству...» ${ }^{17}$.

В соответствии со ст. 19 Протокола № 11 к Конвенции о защите прав человека и основных свобод 1950 г. Европейский Суд по правам человека призван обеспечивать соблюдение обязательств, принятых на себя государствами - участниками Конвенции и исполнение норм Конвенции. Он осуществляет эту задачу путем рассмотрения и разрешения конкретных дел, принятых им к производству на основе индивидуальных жалоб, поданных физическим лицом, группой лиц или неправительственной организацией. Возможна также подача жалобы на нарушение Конвенции государством членом Совета Европы со стороны другого государства-члена. Согласно статье 46 Конвенции надзор за исполнением решений Суда осуществляет Комитет министров Совета Европы ${ }^{18}$. Неисполнение государствами - членами Совета Европы решений Суда может привести к приостановлению членства государства в Совете Европы и, в соответствии с решением Комитета министров исключению государства из Совета Европы.

18 апреля 1995 г. Советом Европы была принята Рамочная Конвенция о защите прав национальных меньшинств. Данный документ считается наиболее полным международным стандартом защиты прав национальных меньшинств ${ }^{19}$. Комментируемая Конвенция уделяет внимание внешнеполитическому аспекту защиты прав национальных меньшинств как важнейшему фактору стабильности и демократии. В документе говорится об обязательствах государств 
относительно доступа, создания и использования национальными меньшинствами средств массовой информации. Новеллой международного законодательства стали положения статьи 16 Конвенции: «Стороны воздерживаются от принятия таких мер, которые, изменяя структурный состав населения в каком-либо регионе проживания лиц, принадлежащих к национальным меньшинствам, имеют целью ущемление прав и свобод, вытекающих из принципов, изложенных в настоящей рамочной Конвенции».

Подробного анализа применительно к рассматриваемой проблеме заслуживают стандарты ОБСЕ в сфере защиты прав человека и гражданина (Заключительный акт СБСЕ, Итоговый документ Мадридской встречи СБСЕ 1980 г., Итоговый документ Венской встречи СБСЕ 1986 г., Декларация Хельсинкской встречи СБСЕ на высшем уровне).

Заключительный акт СБСЕ от 1 августа 1975 г. сформулировал принципы взаимоотношений между государствами-участниками Общеевропейского Совещания, в том числе: уважение прав человека и основных свобод, включая свободу мысли, совести, религии и убеждений; равноправие и право народов распоряжаться своей судьбой; добросовестное выполнение обязательств по международному праву ${ }^{20}$.

Итоговый документ Мадридской встречи СБСЕ 1980 г. (от 06.09.1983г.) подчеркивает важность постоянного прогресса в обеспечении уважения прав лиц, принадлежащих к национальным меньшинствам, и их фактического пользования этими правами, а также в защите их законных интересов, как предусмотрено в Заключительном акте ${ }^{21}$.

Часть 19 Итогового документа Венской встречи СБСЕ 1986 г. (от 15.01.1989 г.) закрепляет, что Стороны будут «защищать и создавать условия для поощрения этнической, культурной, языковой и религиозной самобытности национальных меньшинств на своей территории. Они будут уважать свободное осуществление прав лицами, принадлежащими к таким меньшинствам, и обеспечивать их полное равенство с другими» ${ }^{22}$.

В Парижской Хартии для новой Европы от 21.11.1990 г. провозглашено: «Мы подтверждаем, что этническая, культурная, языковая и религиозная самобытность национальных меньшинств будет защищена и что лица, 
принадлежащие к национальным меньшинствам, имеют право свободно выражать, сохранять и развивать эту самобытность без какой-либо дискриминации и в условиях полного равенства перед законом» ${ }^{23}$.

Декларация Хельсинкской встречи СБСЕ на высшем уровне от 10.07.1992 г. (ч.12) указывает, что «грубые нарушения обязательств ОБСЕ в области прав человека и основных свобод, в том числе тех, которые касаются национальных меньшинств, представляют особую угрозу мирному развитию общества, в частности в новых демократических государствах» ${ }^{24}$. В развитие положений Декларации Хельсинкские решения СБСЕ от 10.07.1992 г. устанавливают, что «Государства-участники активизируют свои усилия по обеспечению свободного осуществления принадлежащими к национальным меньшинствам лицами, на индивидуальной основе и совместно с другими, своих прав человека и основных свобод, включая право участвовать в полной мере в соответствии с демократическими процедурами принятия решений каждого государства в политической, экономической социальной и культурной жизни своих стран, в том числе на основе демократического участия в работе директивных и консультативных органов на национальном, региональном и местном уровнях, в частности в рамках политических партий и ассоциаций» 25 .

Таким образом, ни один из международных актов ООН, документов Совета Европы и стандартов ОБСЕ не позволяет какому-либо государству (группе государств) нарушать права человека и основные свободы, принудительно ассимилировать расово чуждые народы и осуществлять дискриминацию национальных меньшинств.

Между тем, на сегодняшний день сложилась удивительная ситуация, когда целый ряд государств-членов ЕС (Латвия и Эстония) систематически нарушает международные обязательства, игнорирует общепринятые нормы международного права, пренебрегает рекомендациями авторитетных гуманитарных организаций в области прав человека и при этом не несет абсолютно никакой ответственности за содеянное.

Всем известно, к чему привело попустительское отношение руководства европейских стран к проводимым нацистской Германией внутри- и внешнеполитическим акциям против евреев, славян, гораков, кашубов, цыган. 
Подобное малодушие и отрицание проблемы русскоязычного населения в Латвии и Эстонии со стороны лидеров Европейского Сообщества сегодня означает формирование политических режимов с элементами авторитаризма и произвол в странах Балтии завтра. Постоянное издевательство общественных и политических деятелей стран Балтии над частью собственного народа не может продолжаться бесконечно.

Существующее состояние дел должно быть кардинально изменено. Для защиты прав неграждан требуется незамедлительная реализация долгосрочной комплексной государственной программы. На федеральном уровне необходимо создать специальный орган, в компетенцию которого входило бы оказание правовой, социальной, финансовой, информационной и иной поддержки негражданам за рубежом.

Российская Федерация должна развивать сеть общественных организаций, религиозных и культурных центров неграждан в странах Балтии, оказывать этим структурам постоянное содействие (например, в проведении фестивалей, олимпиад, стажировок, научных конференций, книжных выставок, дней русской культуры, реализации совместных Интернет-проектов, выпуске печатной и аудиопродукции и т.п. $)^{26}$.

В отношении государств, нарушающих международные стандарты в гуманитарной сфере, представляется целесообразным использовать дипломатические и политические меры воздействия. В частности, Министерству иностранных дел Российской Федерации предлагается инициировать расширенное обсуждение ситуации с правами русскоязычного населения, обладающего статусом «неграждан» в странах Балтии, на очередной сессии Генеральной ассамблеи ООН, в Верховном комиссариате ОБСЕ по национальным меньшинствам, БДИПЧ, ПАСЕ, Европейской комиссии по борьбе с расизмом и нетерпимостью, Комитете ООН по ликвидации расовой дискриминации и проработать вопрос о характере и сроках применения санкций к государствам - правонарушителям. Что мешает Парламентской Ассамблее Совета Европы или ОБСЕ регулярно обсуждать ситуацию с нарушением прав человека в Чечне наряду с аналогичными злоупотреблениями в странах Балтии? 
В случае бездействия международных и межправительственных организаций, продолжения политики дискриминации неграждан, неприведения законодательства и правоприменительной практики Латвии и Эстонии в соответствие с международно-правовыми и общеевропейскими стандартами в сфере прав человека Российская Федерация могла бы использовать ответные ограничения (реторсии), в том числе экономического характера, в отношении граждан и организаций стран Балтии, находящихся на территории России.

Действенной мерой правовой защиты неграждан являлось бы принятие Федеральным Собранием Российской Федерации закона об упрощенном порядке предоставления российского гражданства «негражданам» и «иностранцам» стран Балтии, изъявившим желание приобрести гражданство Российской Федерации.

Данные меры защиты неграждан должны сопровождаться активной информационной поддержкой и предварительным разъяснением российской и европейской общественности причин и характера предпринимаемых Российской Федерацией действий.

Как представляется, реализация указанных мер была бы более эффективной в формате сотрудничества Российской Федерации с заинтересованными государствами- партнерами из числа участников СНГ.

Источник опубликования: Красинский B.B. О правовом статусе неграждан // Военно-юридический журнал. М.: ИГ Юрист, 2007. № 4. С. 2-7.

1 Понятие «неграждане» используется автором в качестве собирательного термина для характеристики правового положения граждан бывшего СССР, проживающих в Латвии и Эстонии, не имеющих гражданства указанных или других государств, а также зарегистрированных в качестве «неграждан» («иностранцев») в Латвии или Эстонии.

${ }^{2}$ В сентябре 1935 г. во время съезда НСДАП в Нюрнберге были опубликованы два закона, утвержденные Рейхстагом и известные как «Нюрнбергские законы» (Die Nürnberger Gesetze) 15 сентября 1935г.: Закон «Об охране арийской крови и германской чести» и Закон «Об имперском гражданстве (гражданстве германского рейха)». Нюрнбергские законы лишали евреев гражданства, всех политических прав и запрещали браки между арийцами и евреями.

3 Данные социальные общности (евреи и прибалтийские неграждане) имеют поразительно схожие варианты определения их исторической судьбы. К примеру, 23 июля 1938 г. в Германии вышел указ, в соответствии с которым каждый еврей был обязан зарегистрироваться в полиции и получить специальное удостоверение с отметкой «Ј» («еврей»). Согласно Закону Латвийской республики от 12 апреля 1995 г. 
«О статусе тех граждан бывшего СССР, которые не имеют гражданства Латвии или другого государства» каждый негражданин Латвии должен получить фиолетовый паспорт негражданина, отличающийся от синего паспорта граждан Латвийской республики. В Эстонии таким документом стал введенный Законом «Об иностранцах» от 8 июля 1993 г. серый «паспорт иностранца», не признанный большинством государств. Распоряжение нацистов от 17 августа 1938 г. обязывало мужчин еврейской национальности добавлять имя Израэль, а женщин - Сара к своему нееврейскому имени. В 2000-2006 гг. аналогичные мероприятия стали осуществлять в странах Балтии, где массовый характер приобрела практика обязательной «прибалтизации» путем насильственного искажения в паспортах русских фамилий. И кто скажет, что после всего этого «неграждане» чем-то отличаются от нацистских «недочеловеков»? Очередным логичным шагом, вероятно, будет появление гетто или резерваций для неграждан ...

${ }^{4}$ См.: Аргументы и факты // 2004. 12 мая. № 19 (1228).

5 Безусловно, конституционное законодательство многих государств содержит ограничения правосубъектности иностранных граждан и лиц без гражданства в сфере обороны и безопасности, однако в других сферах общественной жизни на иностранцев распространяется национальный правовой режим. Поэтому представляется странным стремление официальных властей Латвии и Эстонии распространить поражение неграждан в правах на сферы науки, культуры, образования и др. К примеру, какую угрозу государственной безопасности и правопорядку Эстонии несет назначение «иностранца» на должность ректора, руководителя публично-правового научного учреждения (ст.18 Закона Эстонской Республики от 12.01.1995 «Об университетах»)? Каким образом защита национальных интересов государства связана с невозможностью «иностранца» быть академиком (ч.1 ст.5 Закона «Об Эстонской академии наук»)? К сожалению, законы прибалтийских государств не дают ответ на эти и другие вопросы и, видимо, не позволят в ближайшем будущем раскрыться талантам многих ученых, инженеров, юристов, деятелей культуры.

${ }^{6}$ См. Ст.2 Закона Эстонской Республики от 29.05.1996 «Об ограничении передачи недвижимой собственности иностранцу, иностранному государству и юридическому лицу»; ст. 21 Закона Эстонской Республики от 17.10.1991 «О земельной реформе»; Закон Латвийской Республики от 30.10. 1991 «О возвращении домовладений законным собственникам».

7 Записка Гиммлера об обращении с местным населением восточных областей / Дашичев В.И. Банкротство стратегии германского фашизма. М., 1973. Т. 1. С. 59-60.

${ }^{8}$ Там же. Т. 1. С. 70-71.

9 По состоянию на 2007 г. в одной только Латвии проживало свыше 400000 неграждан. Все эти люди ущемлены в правах наряду с бывшими сотрудниками органов безопасности и партийными функционерами, в отношении которых действуют законы о люстрации и были проведены показательные политические процессы. В Европейском Суде по правам человека находится около 20 жалоб на Латвию от граждан РФ и этнических русских в связи с депортацией и грубыми нарушениями прав человека. См. дела «Кононов против Латвии», «Сысоевы против Латвии», «Викулов и другие против Латвии», «Сливенко против Латвии», «Жданок против Латвии». Аналогичные жалобы поданы и в отношении Эстонии. См. дело № 14685/04 «Владимир Пенат против Эстонии».

10 Необходимо отметить, что пронацистские симпатии становятся в странах Балтии обыденным явлением. Латвия и Эстония стали единственными странами в мире, где были установлены памятники солдатам СС. 16 марта в Латвии ежегодно отмечается День легиона СС. Стилизованная свастика используется национальнорадикальными латышскими партиями и организациями в качестве символики. В 2000 г. 
эстонский президент Леннарт Мери наградил ветеранов 20 пехотной дивизии СС «за их вклад в восстановление Эстонской республики и за упрочение демократических ценностей». Национализм, возведенный в ранг государственной политики Латвии и Эстонии, позволил ученым-государствоведам утверждать о существовании в этих странах национал-демократических политических режимов. См. Правовые системы стран мира. М.: Норма, 2001. С. 372.

11 Несоответствие объема прав объему обязанностей неграждан нарушает правовые аксиомы теории правоотношений. Почему бы в таком случае не освободить неграждан от части обязанностей (например, от уплаты налогов и сборов), чтобы компенсировать ущемление в правах?

12 См. Действующее международное право. В 3-х томах. Т.2. М.: Изд-во Московского независимого института международного права, 1997. С. 6.

${ }^{13}$ Там же. Т.2. С. 11-16.

${ }^{14}$ Там же. Т.2. С. 30.

15 Там же. Т.2. С. 92. С 1 марта 1999 г. в Латвии вступил в силу новый Гражданско-процессуальный кодекс, в соответствии с которым (ст.13) документы в суды можно подавать только на латышском языке, либо «приобщив в установленном порядке заверенный перевод на государственный язык».

16 Устав Совета Европы от 05.05.1949 г. (ст.3) предусматривает, что все лица, находящиеся под юрисдикцией государства-члена Совета Европы, должны пользоваться правами человека и основными свободами.

17 См. Действующее международное право. В 3-х томах. Т.2. М.: Изд-во Московского независимого института международного права, 1997. С. 113.

${ }^{18}$ Там же. Т.2. С. $139-151$.

19 Эстония ратифицировала Рамочную конвенцию Совета Европы о защите национальных меньшинств с оговорками, которые исключили из юрисдикции документа неграждан. В соответствии с Законом Эстонской Республики «О ратификации Рамочной Конвенции Совета Европы» к национальным меньшинствам относятся только граждане Эстонии, которые проживают на территории Эстонии, имеют давние, прочные и постоянные связи с Эстонией, отличаются от эстонцев своей этнической принадлежностью, своеобразием культуры, религией или языком, руководствуются желанием общими усилиями сохранить свои культурные традиции, религию или язык, служащие основой для их общей идентичности. Аналогичная норма содержится и в Законе Эстонской Республики «О культурной автономии национального меньшинства».

20 См. Действующее международное право. В 3-х томах. Т.1. М.: Изд-во Московского независимого института международного права, 1996. С. 74-78.

${ }^{21}$ Там же. Т.1. С. 82.

22 Там же. Т.1. С. 89. Было бы небесполезно уточнить, как соотносится провозглашенный Итоговым документом Венской встречи СБСЕ принцип защиты и поощрения самобытности национальных меньшинств с отказом Парламента Эстонской Республики предоставить автономию городам Нарва и Силламяэ, населенным главным образом русскими, несмотря на результаты проводившихся там в 1992 г. референдумов.

${ }^{23}$ Там же. Т.1. С. 43.

${ }^{24}$ Там же. T.1. С. 93.

${ }^{25}$ Там же. T.1. C. 182.

26 Учитывая, что 2007 год объявлен указом Президента Российской Федерации Годом русского языка, представляется целесообразным акцентировать внимание европейской и мировой общественности на проводимой странами Балтии кампании по запрету преподавания на русском языке и дискриминации прав неграждан. 